\title{
PSYCHE
}

\begin{tabular}{lll}
\hline Vol. 67 & SePtember, I960 & No. 3 \\
\hline
\end{tabular}

\section{A STUDY OF BEMBIX U-SCRIPTA, A CREPUSCULAR DIGGER WASP}

\author{
By Howard E. Evans \\ Museum of Comparative Zoology
}

One of the most characteristic features of the digger wasp genus Bembix is the almost complete obliteration of the ocelli. Two North American species, arcuata and u-scripta, provide the only important exceptions to this, and these species also possess several other structural features which set them aside from all other species of Bembix. A few years ago I presented some very incomplete data on a colony of $u$-scripta in southern Texas, suggesting at the same time that the behavior of the species ought to prove of unusual interest because of its apparently primitive structural features (Evans 1957). I have recently made further studies of this same colony and also of another small colony in southwestern New Mexico, thus providing an unusual opportunity to compare the behavior of two widely separate colonies of an uncommon species of distinctly localized distribution. These studies also demonstrate that $u$-scripta has one very remarkable feature in its behavior: the females hunt and provision only in the dusk, around and after sunset. Throughout the higher Hymenoptera, large ocelli are distinctly correlated with nocturnal flight. It seems very probable that the preservation of functional ocelli in this species represents an adaptation for flying in the twilight.

A second problem concerns the identity of Bembix arcuata: is this in fact a distinct species from $u$-scripta? 'The Texas colony was located not too far from the type locality of arcuata, the New Mexico colony not far from that of $u$-scripta. The New Mexico wasps had a much more extensively yellow color pattern (more like $u$-scripta), but there was considerable color variation in wasps from both localities. In fact, on the basis of the Texas locality alone, I have already tentatively placed arcuata in the synonymy of u-scripta (Evans 1959). Clearly it will be of interest to see what light behavior sheds on this matter.

In this paper I shall first consider the structural peculiarities of Bembix $u$-scripta and also the differences which are supposed to sepa- 
rate $u$-scripta and arcuata, since this information lends more significane to the behavioral studies. 'There follows a discussion of the ethology of the two colonies studied and finally a brief statement of conclusions. The studies of the Texas colony were made with the assistance of a grant from the National Science Foundation, while those of the New Mexico colony were made during tenure of a fellowship from the John Simon Guggenheim Memorial Foundation. I am indebted to Dr. M. A. Cazier, Director of the Southwestern Research Station of the American Museum of Natural History, for making available the facilities of that station during the summer of 1959. I am also indebted to Drs. Cheng Shan Lin and Oliver S. Flint for assisting me in the field work on the Texas colony. The dipterous prey of the Bembix have been identified by the following specialists, to all of whom I am much indebted: W. L. Downes, R. H. Foote, M. T. James, C. Martin, R. H. Painter, L. L. Pechuman, H. J. Reinhard, C. W. Sabrosky, Y. Sedman, H. V. Weems, and W. W. Wirth.

\section{Morphological Considerations}

The important structural features of Bembix u-scripta and arcuata are given as follows by Parker (1917, 1929) :

I. Ocelli unusually well developed and apparently functional (posterior ocelli with lenses clear, convex, circular except truncated laterally; anterior ocellus in form of a fairly wide transverse band).

2. Second transverse cubital vein of front wing only slightly curved (in other species of Bembix it is sharply bent).

3. Male with basal segment of middle tarsus distinctly curved, its inner surface beset with several stout spines; middle femora of male dentate, middle tibiae ending in a spine-like process.

4. Male with abdominal sternites devoid of processes, but seventh with a pair of carinae which diverge basally.

5. Labrum with a small median elevation (both sexes).

6. Basal segment of front tarsus with an unusually large number of comb-spines (8-IO) (both sexes).

7. Scape of male much thickened.

8. Pygidium of female slightly rugose and with strong lateral ridges.

9. Pattern of yellow maculations unusually strongly developed.

To these nine characters should be added another:

Io. Apical tergite of male with deep longitudinal lateral incisions which cut off a pair of appendages which much resemble the parameres of the genitalia. 
All of these features are unique or shared with only a very few other species of Bembix. Some of them, though unique in Bembix, are shared (at least in some measure) with species of the more primitive bembicine genus Stictiella; these include characters I, 2, and 3 above. Lohrmann ( I948) has studied coloration in Bembix at some length, and has concluded that reduction in color pattern (i.e., less yellow) is correlated with structural advance; thus, on these grounds, character 9 should also be regarded as primitive. The remaining six characters should be regarded as specializations within the genus. However, those which involve the female $(5,6,8)$ are not absolutely unique and the remainder $(4,7$, ro) involve male secondary sexual characters, which are remarkably plastic in the bembicine wasps. The more striking features thus suggest that these wasps do, in fact, retain several features which may have been characteristic of the ancestral Bembix, though obviously an assortment of specializations of a less striking sort have been acquired.

In describing Bembix arcuata, Parker (I9I7) listed the following characters by which it differed from u-scripta (Fox I895):

I. The nature of the male "genital stipes" (i.e., parameres), which are much more slender and attenuate than in u-scripta.

2. Mesosternum marked with black (yellow in u-scripta).

3. Abdominal sternites 2-4 with small lateral yellow spots (in $u$-scripta these are more extensively yellow and there is some yellow on the sternites behind these).

4. Apical sternite black (yellow in u-scripta).

Since the first of these characters involves an important structural distinction, it should be considered first. Parker based his interpretation of $u$-scripta on the type specimen, one other male, and four females. I have examined these two males and find that it is true that the parameres are less attenuate than in the type of arcuata - or in males from both colonies studied. However, the difference is slight and relative, and I cannot agree with Parker that the genitalia "differ widely". Parker's figures tend to exaggerate the differences between the two: yet the differences cannot be entirely reasoned away.

Study of the color characters supposed to separate these species reveals that while they may apply to the type specimens, they are by no means absolute when additional specimens are considered. The type of $u$-scripta is almost wholly yellow, that of arcuata predominantly black. Specimens from the Texas colony which I studied are close to arcuata, but exhibit enough variation to cause confusion in using Parker's key. 
Specimens from the New Mexico colony are close to $u$-scripta, but again they do not agree perfectly and there is much variation to be considered. When specimens from other localities are considered also, it becomes obvious that the extent of maculation varies in a complete spectrum all the way from "arcuata" to " $u$-scripta". I have tabulated the variation in two color characters ('Tables I and II), selecting these two merely because Parker emphasized them. I have also studied other characters, such as the very noticeable variation in the development of the U-shaped markings on the mesoscutum, with very similar results. This species has not been collected in enough localities to enable one to be certain of the relation of geography to color pattern, but the available evidence suggests a northwest to southeast cline.

Table I. Color of Apical Sternite of Female

\begin{tabular}{lccc}
\hline Locality & \multicolumn{3}{c}{ Number of Specimens } \\
\cline { 2 - 4 } & $\begin{array}{c}\text { Largely yellow } \\
\text { apically }\end{array}$ & $\begin{array}{c}\text { Tip yellow } \\
\text { all across }\end{array}$ & $\begin{array}{c}\text { Tip yellow } \\
\text { on sides }\end{array}$ \\
\hline California $^{1}$ & 2 & & \\
Wellton, Ariz. & 1 & 7 & \\
Rodeo, N. Mexico & 2 & 4 & \\
Lordsburg, N. Mexico & 1 & 2 & 42 \\
$\begin{array}{l}\text { Albuquerque, N. Mexico } \\
\text { Mexcala, Guerrero }\end{array}$ & & 1 & \\
Pt. Isabel, Texas & & & \\
\hline
\end{tabular}

Table II. Color of Mesosternum of Male

\begin{tabular}{lcccc}
\hline \multicolumn{1}{c}{ Locality } & \multicolumn{3}{c}{ Number of specimens } \\
\cline { 2 - 5 } & $\begin{array}{c}\text { Almost } \\
\text { wholly } \\
\text { yellow }\end{array}$ & $\begin{array}{c}\text { Black spots } \\
\text { posteriorly }\end{array}$ & $\begin{array}{c}\text { Posterior.6-.8 } \\
\text { black, some } \\
\text { on pleura }\end{array}$ & $\begin{array}{c}\text { Sternum and pleura } \\
\text { black except } \\
\text { anterior border }\end{array}$ \\
\hline $\begin{array}{l}\text { Tucson, Ariz. } \\
\text { Rodeo, N. Mex. }\end{array}$ & 2 & & & \\
Lordsburg, N. Mex. & 9 & & \\
Mesilla, N. Mex. & 1 & & \\
Pt. Isabel, Tex. & 1 & 24 & 5 \\
Cotulla, Tex & & 9 & 2 & 1 \\
\hline
\end{tabular}

1 Paratypes of $u$-scripta, bearing no further locality data. These specimens otherwise have the yellow maculations generally reduced as compared to Arizona specimens, and also have a large black spot on the clypeus.

2 Types of $u$-scripta

3 Paratype of arcuata

4 Type and paratypes of arcuata

Observations on Colony at Port Isabel, Texas

This colony was first discovered June 23-25, 1956, but at this time it was evident that the wasps had nearly completed their activities for 
the season. Only a few females with badly worn wings and mandibles were still active, and even these ceased activity after June 25 (Evans I957). I returned to the area May 8-II, I958, and found the wasps at the peak of their activity. C. S. Lin revisited the area June 3-7 of the same year and found that the males had disappeared and that nesting of the females was more advanced. Thus in this area the wasps first become active in early May (probably in late April) and the females remain active for six to eight weeks. The species is certainly univoltine, as cocoons collected June 23, 1956, gave rise to adult males and females in late March, 1957 (they were overwintered at room temperature at Ithaca, N. Y.).

The colony was located on the protected beach of Laguna Madre about five miles west of Port Isabel. The soil here is a rather heavy, dark sand containing pieces of shells and bits of organic matter (chiefly bits of decayed seaweed and beach halophytes). This beach is occasionally swept by waves from Laguna Madre (which is salt), especially during the fall and winter, but there is little tide action. On certain parts of the beach there are extensive patches of low vegetation, chiefly Salicornia, certain composites, and various grasses. The wasps occurred only in bare places on the middle of the beach, that is, from about 8 to I 5 meters above the high water mark but below the banks at the upper edge of the beach.

Behavior of males. - Males were observed only during early May, 1958, but at that time they were very abundant. Each morning we entered the area about 0800 , and at this time the males were already engaged in their "sun dance". Each male flew rapidly in loops, figure eights, and irregular patterns only $2-6 \mathrm{~cm}$. above the sand surface, much as in Bembix cinerea (Evans 1957). By IO30 some reduction of males could be noted, and by II 15 each day the last male had disappeared. By 1500 a few males were once again active, and from I600-I900 each day there was a second though somewhat less populous sun dance. The greater part of this sun dance occurred in a small area somewhat apart from the major nesting area of the females, although males often flew briefly over various parts of the beach before rejoining the sun dance.

During the middle of the day, and also at night, the males enter short, oblique burrows in the sand and throw up a small barrier of sand behind them. These burrows tend to be grouped in small clusters. They are dug by the males, but the males usually re-enter an old burrow rather than digging a new one each day. 
During the sun dance the males fly, at least some of the time, with their middle and hind legs hanging down. When they approach a female they attempt to descend upon her from above and grasp her with the legs. During this time the pair rise a meter or two in the air, then, if the female is receptive, descend to the ground, where copulation occurs. During mating, the male rcsts on top of the female, often buzzing his wings (perhaps to maintain balance), while the female remains completely motionless, her wings being clamped in place by the middle legs of the male. The spines of the middle femora of the male apparently fit over the wing-bases of the female, while the arcuate middle tarsi of the male appear to fit over the coxae of the female. The front legs of the male extend rigidly forward and the hind legs rigidly backward during copulation; neither pair is in contact with the female or the substrate. The male genitalia are of course extruded and work up and down rhythmically until they gain entry into the genital chamber of the female. The longest copulation observed lasted two minutes.

Nesting behavior of females. - Most of the females were concentrated in one large bare area on the beach. In this area there were at least IOO nests, many of them only a few centimeters apart. Nests on the periphery of the colony tended to be more widely separated. Here and there along the beach there were other smaller groups of nests, so that the total may have approximated 200.

Most new nests appear to be started in the morning (o9oo-1030). The female is able to dig about $10 \mathrm{~cm}$. an hour, but because of frequent periods of inactivity, especially at midday, the greater part of a day is generally required to complete a nest. Much use is made of the mandibles in loosening the soil, and this results in much wear of the mandibles as the season progresses. The soil which is loosened is scraped back with the front legs in the usual manner of wasps of this genus. When the burrow is a few centimeters deep, the wasp allows the soil to clog the entrance, sometimes for long periods, before finally coming out and scraping it back from the entrance. The digging movements appear rather slow as compared to other species of the genus.

As digging progresses, a large mound of sand accumulates behind the entrance. This mound measures, on the average, about $18 \mathrm{~cm}$. long, Io $\mathrm{cm}$. wide, and $1.5 \mathrm{~cm}$. high. When the nest is completed, some individuals level this mound. The leveling movements are very characteristic and unlike those of any other known Bembix. The fe- 
male (without closing the ncst entrance) backs out to the middle of the mound of sand, then walks forward in a straight line scraping sand backward. When she arrives at the nest entrance, she turns to one side at a $45-90^{\circ}$ angle and continues for another I-3 centimeters, still scraping sand, which now falls over or slightly beyond the nest entrance. She then flies back to the center of the mound and repeats
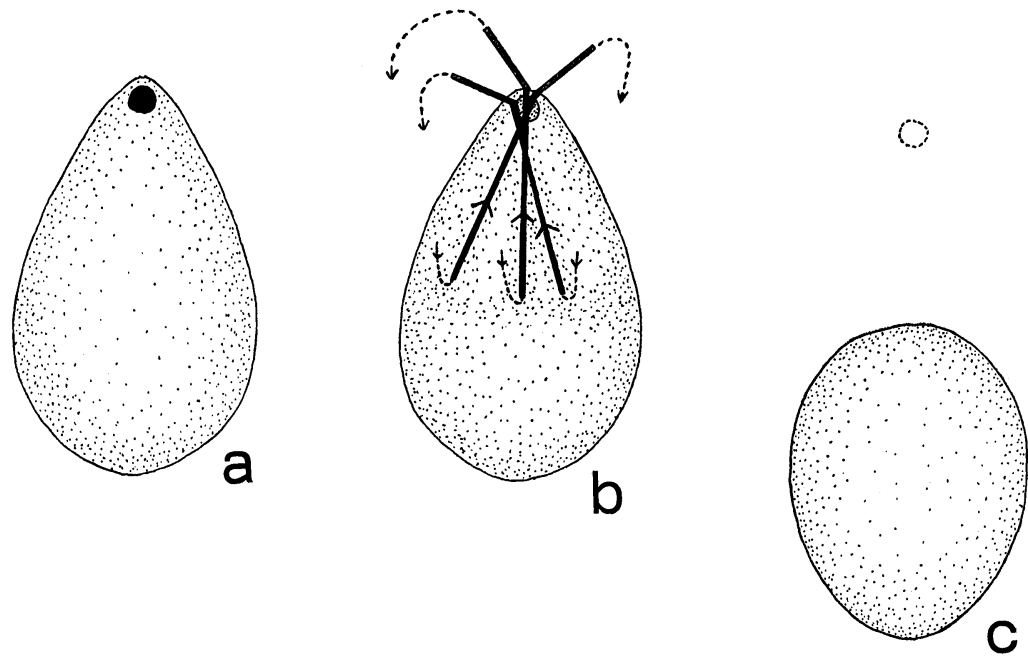

Fig. 1-Diagram of leveling movements of Bembix u-scripta. In $a$ is shown the completed mound of earth with the open (blackened) nest entrance at one end. In $b$ three typical routes of a female leveling the mound are shown; dashed lines indicate movement by flight. In $c$ is shown the final product, with the nest entrance covered (indicated by dashed line) and mound well removed from entrance.

the performance. After a time this results in the soil immediately in front of and around the nest entrance being well scattered and flattened. However, the extremity of the mound of soil has not been touched and has in fact been added to. Thus the net result of the leveling movements is to move the bulk of the accumulated soil from the nest entrance to a position well removed from it (by about 8-I2 cm.) (fig. I).

In this colony relatively few individuals leveled the mound. We estimated that about $25 \%$ leveled, while some others exhibited weak and indefinite leveling movements. The remaining members of the colony left the mound of earth completely intact. As additional cells are added to the nests, some additional soil is added to the mound; 
as a result nests containing several cells often have a very large mound of earth (as much as $3 \mathrm{~cm}$. high). It was our impression that individuals that level following completion of the initial cell also level after each additional cell, but our data on this point are weak.

When the nest or new cell is completed, and leveling is completed if this is to occur, the female flies off to obtain her first fly, on which the egg is laid. This invariably occurs in the late afternoon or early evening, and after oviposition the female closes the nest from the inside for the night. Thereafter the nest entrance is left closed from the inside when the female is inside for long periods of time (at night and during much of the day). During these periods the cell is also closed off from the burrow by a small barrier of sand. The female remains in the bottom of the burrow just outside this barrier or "inner closure". During periods of provisioning, however, both inner and outer closeures are removed. Nest entrances are occasionally found to be open for brief periods in the morning, probably while the female is out taking nectar from flowers. In this area no wasps were actually observed visiting flowers. Final closure of the nest is not especially distinctive and has already been described (Evans 1957).

Description of nest. - The burrow measures about $15 \mathrm{~mm}$. in diameter, generally slightly more than this near the entrance. It enters the soil at a $45-70^{\circ}$ angle with the horizontal but tends to level off as it approaches the horizontal cell. The burrow is often straight but may have a weak to strong lateral curve part way down. Measurements of 36 nests showed the burrow length to vary from 19 to 40 $\mathrm{cm}$., with a mean of $30 \mathrm{~cm}$. Depth of the bottom of the cell, measured vertically from the soil surface, varied from io to $22 \mathrm{~cm}$., with a mean of $15 \mathrm{~cm}$. Cells measured about $18 \mathrm{~mm}$. in diameter and from 30 to $40 \mathrm{~mm}$. in length.

Of I6 nests dug out May 8-I I, I958, I 4 contained one cell and two contained two cells; none of these nests had yet received the final closure and hence all might have eventually had additional cells. Of 20 nests dug out by C. S. Lin June 4-7 of the same year, I I contained one cell, 8 contained two, and one contained three. Only a few of these (including the three-celled nest) had received the final closure. The several nests dug out in late June, I956, were nearly all multicellular (Evans 1957). Two nests were tricellular; one of these was still active while the other was receiving the final closure when dug out. Two other nests appeared to have four cells and another five. However, in these cases all the cells contained cocoons and the burrows 
leading to them had been filled and hence could not be traced accurately. Because of the close proximity of nests in this colony, it is impossible to be certain that all of these cells belonged to the nest in question. The evidence now seems strong that the nest is usually closed after the completion of only two or three cells. It is not improbable that one-celled nests also occur, perhaps also four or fivecelled nests rarely. Two or three-celled nests are characteristic of Bembix nubilipennis (unpublished observations), while B. cinerea and $B$. belfragei characteristically make one or two-celled nests (Evans I957).

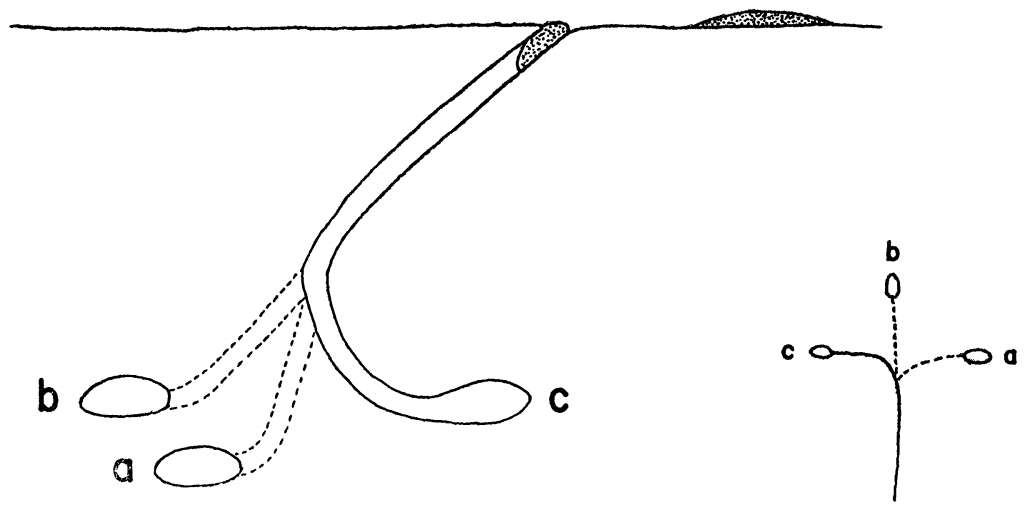

Fig. 2. - Typical three-celled nest of Bembix u-scripta (our field note no. 1635, Rodeo, N. Mex.). Cell a contained a completed and hardened cocoon, so was obviously the first cell of the nest. Cell $b$ contained a fresh, still soft cocoon; cell $c$ was a new cell which was empty when the nest was dug out. The figure on the left shows the nest in lateral view, compressed to a single plane, while the sketch on the right shows the proper relationship of the cells in a horizontal plane.

The cells of a given nest are normally separated by several centimeters of soil. After the first cell is fully provisioned, the bottom .3 to .5 of the burrow is packed tightly with sand. The wasp then constructs another section of burrow of about equal length at roughly a $90^{\circ}$ angle with the main burrow and builds the second cell at the end of it. The third cell-burrow and cell are normally constructed from the opposite side of the main burrow (fig. 2).

Provisioning. - During the first two days of study, we were unable to find females provisioning their nests even though the nests which we dug out usually contained fresh flies. We left the area on these days at I600-I700, a time when most digger wasps have completed 
their activities for the day. On the third day we noted a few females provisioning their nests about 1600 , and remained in the area until 1915. We discovered that there was a great emergence of females from their nests just before sunset. During the two-day period of observation, the first female carrying prey was seen at 1520 , the last at 1905 , with the great bulk of the provisioning occurring between I 700 and I900. Sunset was at about I830. Some females and males were still active at 1915, when it was too dark for us to see them well, but apparently these individuals were merely digging in for the night.

In order to determine what types of flies the wasps were taking at this unusual hour, we took 97 flies from females or from the nests. These flies represented 33 species of nine families; that is, there was an average of only three flies of any one kind. The most numerous flies were those of the genus Acrosticta (Otitidae) (26 examples). Bombyliidae, Asilidae, and Tachinidae were represented in roughly equal numbers, each family by several species. A complete list is presented in Table III. Although many species of Bembix are relatively unselective of their flies, I have never encountered a more remarkable diversity of prey in any one locality. Most of the flies used were relatively small, and a great many of them were used per cell (about 4O). However, some relatively large flies were found in some nests.

It required very little study to determine that virtually all Diptera had ceased activity by the time the Bembix began to provision in numbers. Some of the flies (e.g., the otitids, and some of the bombyliids and sarcophagids) were seen commonly on the beach during the middle of the day, but in the evening they had disappeared. The Bembix apparcntly hunt widely in the vegetation and take virtually any "sleeping" flies within a certain size range which they encounter there.

Females carrying flies enter the nesting area with a rather loud buzzing only 10-2O centimeters high. They plunge quickly into the nest entrance which, as noted above, is never closed during provisioning. In less than a minute, they re-emerge from the burrow and quickly take wing. Several instances were observed of females attempting to steal flies from one another.

Oviposition and development. - The first fly is placed deep in the cell on its back, head-in, with one wing somewhat extended. The egg is laid erect, glued to the side of the fly near the base of the extended wing, or actually glued to the wing-base. One instance of abnormal oviposition was observed. In this case the fly (Acrosticta sp.) was actually smaller than the egg and was dorsum-up, with the egg of the wasp glued to the base of the abdomen and extending obliquely for- 
ward. The egg of $u$-scripta measures about $4.5 \mathrm{~mm}$. long.

The egg hatches in about two days and the small larva remains attached to the fly pedestal by a glutinous thread for several days. Provisioning is fully progressive; that is, flies are provided each day up until the larva is full-grown and nearly ready to spin its cocoon. The wasp does not clear the fly remains from the cell, and they merely accumulate in a mat on the bottom of the cell. Apparently about a week is required for completion of larval development.

TABLE III. PREY OF BEMBIX U-SCRIPTA AT PORT ISABEL, TEXAS

\begin{tabular}{|c|c|}
\hline Family and species of fly & Number taken \\
\hline \multicolumn{2}{|l|}{ STRATIOMYIDAE } \\
\hline Hermetia aurata Bell & 1 \\
\hline \multicolumn{2}{|l|}{ TABANIDAE } \\
\hline Tabanus texanus Hine & 1 \\
\hline \multicolumn{2}{|l|}{ BOMBYLIIDAE } \\
\hline Aphoebantus sp. nr. hirsutus Coq. & 6 \\
\hline Lordotus gibbus gibbus Lw. & 5 \\
\hline L. gibbus striatus Painter & 3 \\
\hline Phthiria sp. & 1 \\
\hline Poecilanthrax lucifera Fabr. & 3 \\
\hline Villa parvicornis Lw. & 2 \\
\hline \multicolumn{2}{|l|}{ ASILIDAE } \\
\hline Erax cressoni Hine & 2 \\
\hline E. tuberculatus Coq. & 4 \\
\hline Pleisosomma unicolor $\mathrm{Lw}$. & 1 \\
\hline Psilocurus madestus Will. & 2 \\
\hline P. puellus Bromley & 2 \\
\hline Stenopogon ebyi Bromley & 6 \\
\hline \multicolumn{2}{|l|}{ SYRPHIDAE } \\
\hline Volucella fraudulenta Will. & 1 \\
\hline V. unipunctata Curran & 3 \\
\hline V. sp. & 1 \\
\hline \multicolumn{2}{|l|}{ OTITIDAE } \\
\hline Acrosticta mexicana Cole & 15 \\
\hline A. sp. & 11 \\
\hline \multicolumn{2}{|l|}{ MUSCIDAE } \\
\hline Limnophora sp. & 1 \\
\hline Mydaea sp. & 1 \\
\hline Phyllogaster cordyluroides Stein & 5 \\
\hline \multicolumn{2}{|l|}{ SARCOPHAGIDAE } \\
\hline Sarcophaga johnsoni Ald. & 4 \\
\hline$S$. sp. & 1 \\
\hline Senotainia kansensis 'Tns. & 1 \\
\hline \multicolumn{2}{|l|}{ TACHINIDAE } \\
\hline Archytas marmoratus Tns. & 1 \\
\hline Chaetogaedia sp. nr. analis Wulp & 1 \\
\hline Goniochaeta plagioides Tns. & 1 \\
\hline Opelousia obscura Tns. & 1 \\
\hline Phorocera tachinomoides Tns. & 1 \\
\hline Promasiphya confusa $\Lambda \mathrm{ld}$. & 1 \\
\hline Tachinophyto sp. nr. vanderwulpi Tns. & 3 \\
\hline Xenoppia monela Rnh. & 7 \\
\hline
\end{tabular}




\section{Observations on Colony at Rodeo, New Mexico}

This small colony of Bembix u-scripta was discovered on August 28, 1959, in open desert at about 4000 feet elevation one mile north of the town of Rodeo, in extreme southwestern New Mexico. The area in question has only a few shrubs and small trees (chiefly mesquites and yuccas), but following the summer rains it is densely covered with composites and other flowering annuals, Russian thistle, and grasses. Here and there are small places devoid of vegetation. In some of these the ground is flat and the soil rather compacted, while in others the soil is loose, sandy, and somewhat blown-out or piled up in small dunes no more than a meter or two high. One of these small dunes contained about six nests of Bembix u-scripta, while two other nests were found in similar places not far distant. A colony of Aphilanthops haigi was located in the same dune with most of the Bembix nests, the nests of the two wasps intermingled. A few specimens of Bembix sayi and $B$. Similans also nested within the total area inhabited by $B . u$ scripta.

Many things about this situation were strikingly different from the Port Isabel location. The season was of course different, though August is properly considered "spring" in this area, as the summer rains occur in July and August and result in a great flowering of the desert and in the appearance of many Hymenoptera. The soil here was of finer texture, more friable, and apparently drier, although occasionally moistened temporarily by showers. No tests were made to determine whether the soil was of comparable salinity, but surely it was not, as this is not an area of notable internal drainage such as occur in some parts of the Southwest.

The total population of Bembix u-scripta in this area may have been no more than 30 to 40 individuals of both sexes. Consequently, in spite of the longer period of study (August 28- September 12), my data are more fragmentary. However, I was especially alert for resemblances to and differences from the Texas colony, and the following account stresses these.

Behavior of males. - The first males were observed August 2 I flying over certain bare, sandy patches, although no females were discovered until a week later. The flight of the males was extremely rapid and the pattern of flight very irregular; it was only after many failures that I succeeded in taking one for identification. There were scarcely enough males for a typical "sun dance", though now and then two or three would fly about the same small area and make contact 
with one another in flight briefly. Males were generally active o8ooII3O and again, in lesser numbers, I600-1800. Several were seen visiting the flowers of Gaillardia pulchella for nectar, as were several females. At 1630 on September 8 a pair was seen in copula on these flowers. They remained together for two minutes, then separated briefly and once again came together. The details of copulation were essentially as described for the Texas colony.

Nesting behavior of females. - The nests in this area tended to be well separated, the closest nests being about half a meter apart. New nests were started in the morning and completed in the late afternoon; during much of the day the entrance to such a nest would be closed with a plug of sand thrown up from the inside, where the female was presumably resting or digging only intermittently. During the more active periods of digging the wasp now and then comes out and clears the sand from the entrance. Eventually a fairly large mound of sand accumulates outside the entrance. When the nest is completed, the female comes out (without closing the entrance behind her) and commences to level this mound of sand. The leveling movements were found to be precisely the same as in the Texas colony (fig. I). They result in the mound being not so much leveled as spread out and moved slightly farther from the nest entrance. Following leveling, the $10 \mathrm{~cm}$. directly in front of the entrance are typically smooth, with beyond this the mound, measuring about $20 \mathrm{~cm}$. long by $\mathrm{I} 8 \mathrm{~cm}$. wide. Leveling was observed several times and little variation was noted; always it occurred in late afternoon and required 15-25 minutes. Following completion of a new cell in an old nest, little additional sand is usually thrown out, but such sand as accumulates is treated in the same manner. Also, when a female emerges from her nest in the late afternoon and is about to begin bringing in prey, she clears the entrance of sand and proceeds to level this sand briefly in the same manner. All individuals observed exhibited these leveling movements.

The general structure of the nests in this area was very much as described for the Texas colony. However, they were slightly deeper. In the eight nests which were dug out, burrow length varied from 30 to $42 \mathrm{~cm}$. (mean $35 \mathrm{~cm}$.), cell depth from 16 to $23 \mathrm{~cm}$. (mean $\mathrm{i} 8$ $\mathrm{cm}$.). Five of the eight nests had but one cell, while two had two and one had three (fig. 2). None of these nests had received the final closure when I dug them out, so all might eventually have had more cells. However, since I saw several females digging new nests toward 
the end of the period of observation, I doubt if the number of cells per nest is normally more than two or three.

Nests dug out when the female was not provisioning were invariably found to have two closures, one at the entrance and one just outside the cell, with the female remaining just outside the inner closure. During provisioning, and also when the female is out taking nectar from flowers, the outer closure is not maintained, though the inner closure is normally maintained if the cell contains an egg or small larva.

Provisioning. - All provisioning occurred in the late afternoon and early evening, as in the Texas colony. During the period of observation, sunset occurred at about $1820-1830$. However, the area in question was located directly east of the Chiricahua Mountains; the sun disappeared behind these shortly after 1800 , leaving the area in deep shadow. The first female carrying prey was observed at 1600 , the last at I $\Omega_{42}$, with the bulk of the provisioning occurring between 1730 and 1830 . September io was a cloudy day, and several females were out of thenests earlier than usual (by I430); however, none were seen with prey until about I700.

Several females were observed hunting flies. They would fly about tall herbs (especially Russian thistle, Salsola kali tenuifolia) and actually fly in amongst the branches. Evidently they were searching for flies resting on the vegetation, for at this hour no flies were active. I was able to obtain only a few records of prey (Table IV). The wasps normally provide only a few fresh flies each evening, and nests dug out in the morning usually have few intact flies if any. It appeared that Bombyliidae provided the major prey in this area. Females provision very rapidly, entering the nests quickly and remaining inside only I5-30 seconds each time. One female was observed to bring in eleven flies in one hour ( $1720-1820$ ).

TABLE IV. PREY OF BEMBIX U-SCRIPTA AT RODEO, NEW MEXICO

\begin{tabular}{|c|c|}
\hline Family and species of fly & Number taken \\
\hline THEREVIDAE & \\
\hline Chromolepida pruinosa (Coq.) & 1 \\
\hline BOMBYI.IIDAE & \\
\hline Phthiria sulphurea Loew & 2 \\
\hline Villa (Chrysanthrax) sp. & 1 \\
\hline V. (Villa) salebrosus Painter & 1 \\
\hline SARCOPHAGIDAE & \\
\hline Sarcophaga sp. & 1 \\
\hline $\begin{array}{l}\text { TACHINIDAE } \\
\text { Olenochaeta kansensis Tns. } \\
\text { Phorocera sp. }\end{array}$ & $\begin{array}{l}1 \\
1\end{array}$ \\
\hline
\end{tabular}


Oviposition and development are as described for the Texas colony. Invariably provisioning occurs until the larva is nearly ready to spin its cocoon.

\section{Summary and Discussion}

Despite the difference in season and ecological situation, the members of the two colonies studied exhibited striking resemblances in nesting behavior. The slightly deeper nests of the New Mexico colony were doubtless correlated with the lighter texture of the soil. As a general rule, with reference to populations of a single species or closely related species, wasps nesting in looser soil tend to make deeper nests. In this instance the difference in nest depth is slight, and it would be rash to claim that it is genetically determined. The fact that the New Mexico colony was much smaller and had the nests much more widely scattered may merely mean that this area was ecologically marginal for the species or that this population had undergone a decline because of unknown physical or biological factors.

The one difference which is more diffcult to reason away pertains to the numbers of individuals exhibiting leveling movements. In the New Mexico colony, although the number of individuals observed was not large, all appeared to level the mound at the nest entrance in the manner characteristic of the species. In the Texas colony the majority did not, but roughly $25 \%$ of the individuals leveled in exactly the same way as the members of the New Mexico colony. It would be most interesting to study colonies from other parts of the range in this regard. It is conceivable that this percentage may be found to reflect a difference in gene frequency which varies clinally somewhat as color pattern appears to do in this species. On the other hand, one cannot be certain that even this difference is genetic; it is possible that the movements are innate but subject to threshold factors which were dependent upon the differing ecology of the two areas.

On the whole one cannot help but be much impressed by the similarity in the nesting behavior of these two widely separated colonies as well as the several unique features in the behavior of the species. In the following paragraphs some of the more significant features of the behavior are discussed one by one.

( I) The species is crepuscular, at least with respect to hunting and provisioning. Some females begin hunting 2.5-3 hours before sunset, but the majority do not become active until about an hour before sunset. From then on until about half an hour after sunset most females leave the nest entrance open and are actively provisioning. The 
last females close the nest at about the time it becomes difficult for a human to observe them without artificial illumination. So far as I know this is unique among digger wasps.

(2) The females hunt flies which are at rest in herbaceous vegetation. The wasps fly in amongst the plants and presumably snatch the flies from the leaves and branches. This is in marked contrast to other Bembix, which pursue flies visiting flowers or flying about animals, dung, etc. The flies taken by $u$-scripta are exceedingly diverse and generally rather small for the size of the wasp.

(3) The mound of earth at the nest entrance is leveled in a manner unlike that of any other North American Bembix, though bearing some resemblance to that of spinolae and several other species.

(4) The nest is multicellular (apparently usually bicellular or tricellular), much like that of nubilipennis.

(5) The nest entrance is left open during provisioning but is at all other times closed from the inside (somewhat as in sayi).

(6) The egg is laid on the first fly (as in all but a few of the more specialized species of Bembix.)

(7) The cell is of simple structure and is not cleaned by the female.

Of these seven characteristics, the first three are unique, the fourth and fifth unusual although not unique, the last two common to all the more generalized species of Bembix (several more characters of this nature could easily be tabulated). Thus the total picture is not unlike that obtained from a study of structure: several unusual features built into a basically primitive Bembix. The most interesting of these features pertain to the unusual time of flight of provisioning females and the fact that they take Diptera which are at rest in vegetation. The well developed ocelli probably represent part of the morphological component of this adaptive complex. Since the ancestral Bembix doubtless had ocelli of nearly normal sphecid type, it seems probable that $u$-scripta split off from this stock at a very early date, before the loss of ocelli became complete. This would also account for the fact that certain features of wing venation and male secondary sexual characters are more Stictiella-like than Bembix-like. The crepuscular provisioning behavior of $u$-scripta clearly enables the species to exploit a slightly different source of food from that of other species of the genus: a miscellany of mostly rather small flies which are snatched from their resting positions in vegetation. So far as can be judged at present, $u$-scripta is not strongly restricted ecologically; perhaps the 
species is able to live side-by-side with other Bembix by virtue of its unusual provisioning behavior. Since $u$-scripta is one of the rarest of North American Bembix, I would hesitate to say that its unusual adaptations have proved outstandingly successful.

A final word on the second problem, that of the specific status of arcuata and $u$-scripta. I find it hard to believe that the wasps which I studied at Port Isabel, Texas, and Rodeo, New Mexico, represent different species. As indicated earlier, the Texas wasps were colored much like the type of arcuata, the New Mexico wasps much like the type of $u$-scripta. However, they were not colored precisely like the type of $u$-scripta and the parameres of male genitalia were more slender and attenuate than they appear to be in the type of that species. The final solution must come from studies farther west, from in and around Tucson, Arizona, the type locality of $u$-scripta. In the meantime I see no reason to abandon my former belief that the two names should tentatively be regarded as synonyms.

\section{Literature Cited}

Evans, H. E. 1957 Studies on the comparative ethology of digger wasps of the genus Bembix. Cornell Univ. Press. $248 \mathrm{pp}$.

1959 Studies on the larvae of digger wasps (Hymenoptera, Sphecidae). Part V: Conclusion. Trans. Amer. Ent. Soc., 85: 137-191.

Lohrmann, E. 1948 Die Grabwespengruppe der Bembicinen. Überschau und Stammesgeschichte. Mitt. Munchen. Ent. Ges., 34: 420-432.

PAR KER, J. B. 1917 A revision of the bembicine wasps of America north of Mexico. Proc. U. S. Nat. Mus., 52: 1-155.

1929 A generic revision of the fossorial wasps of the tribes Stizini and Bembicini. Proc. U. S. Nat. Mus., 75 (art. 5) : 1-203. 

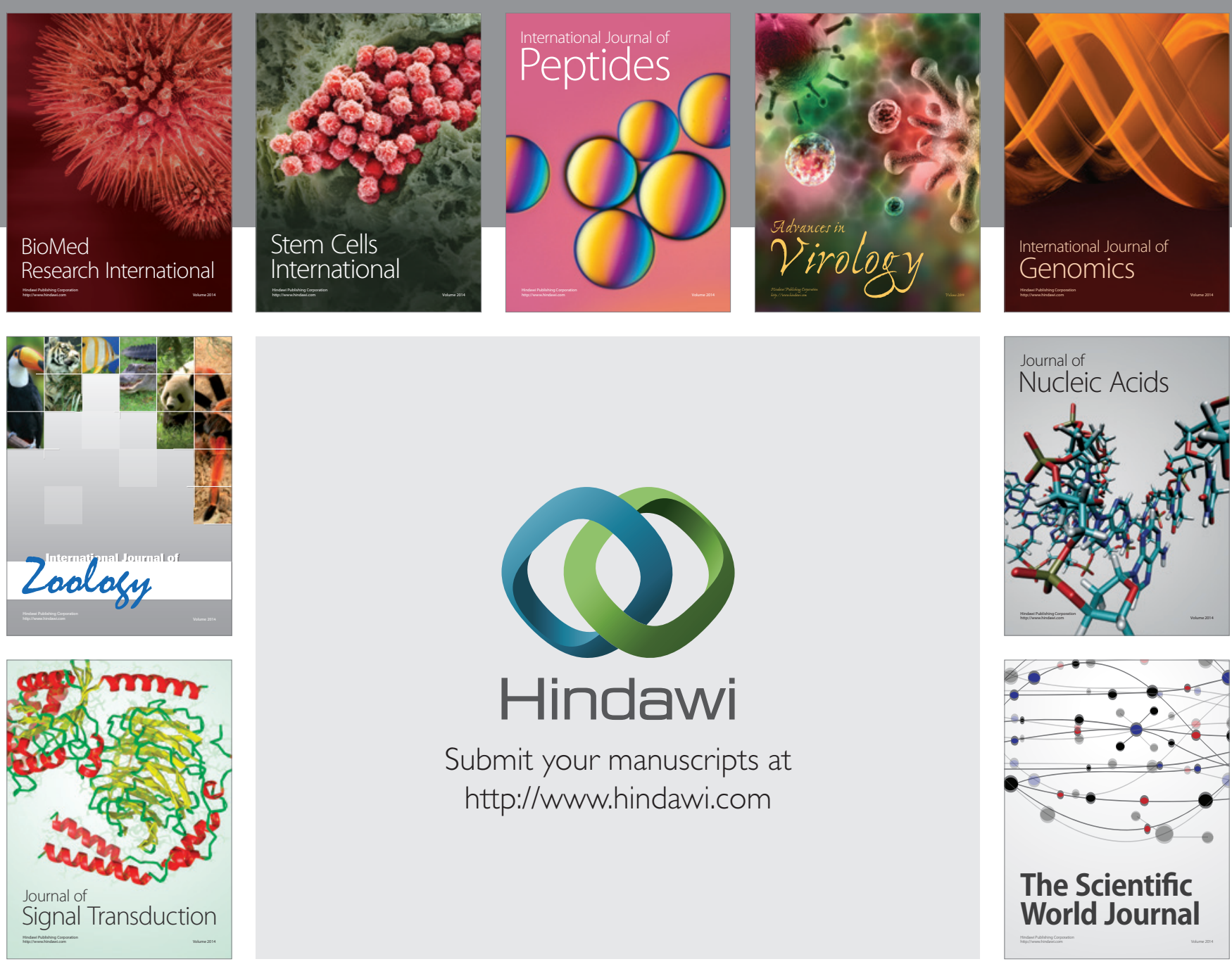

Submit your manuscripts at

http://www.hindawi.com
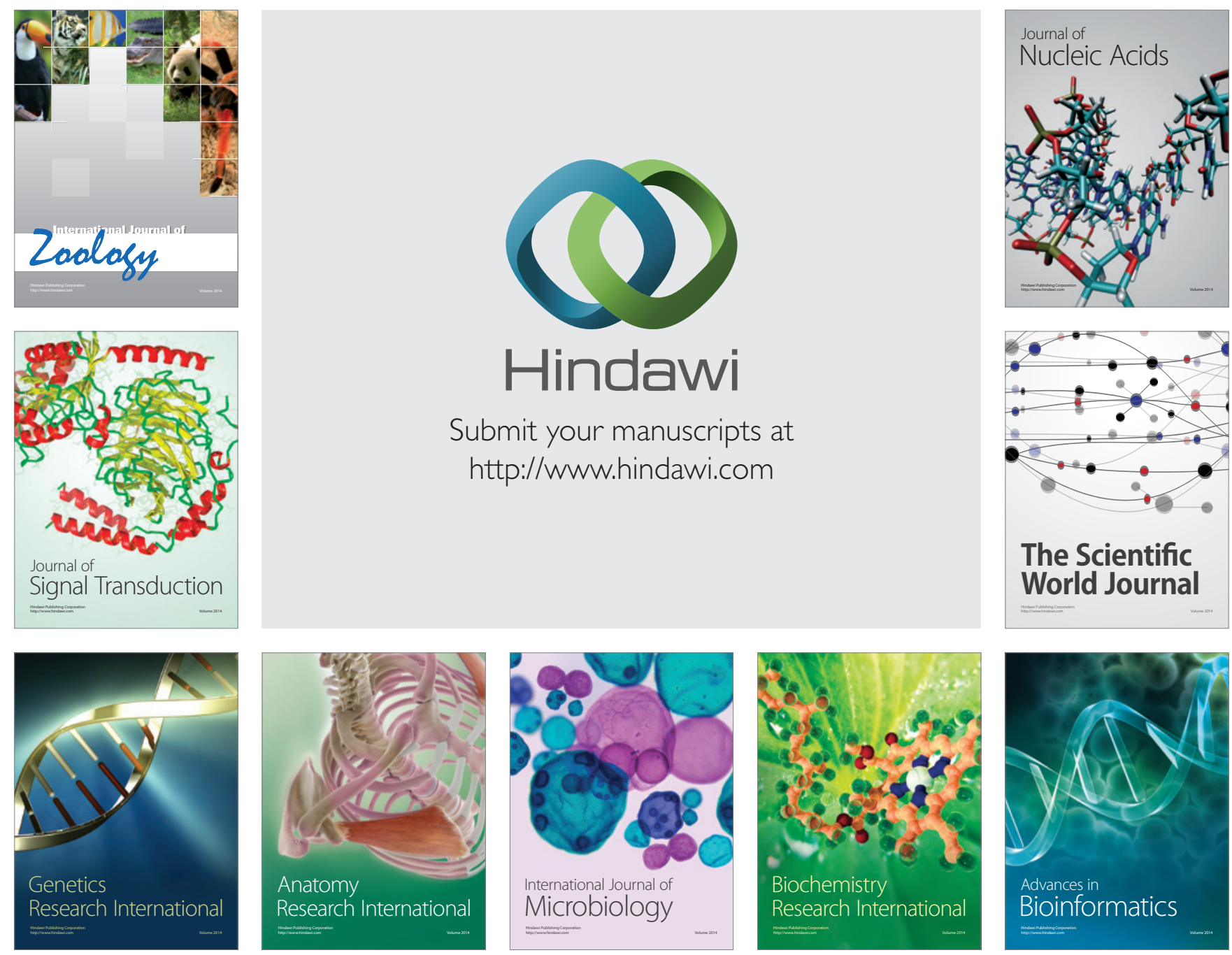

The Scientific World Journal
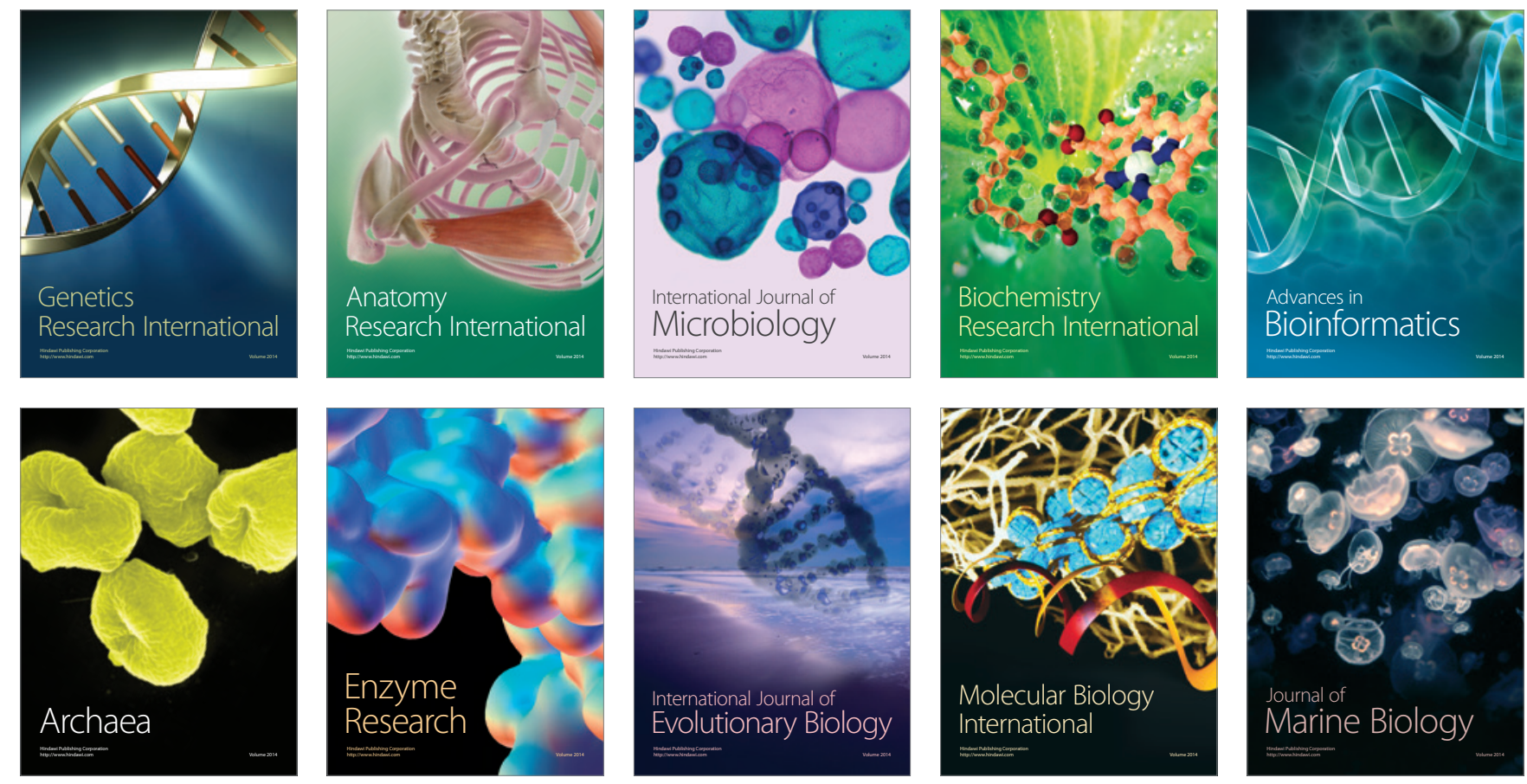